\title{
The effect of inoculants and cellulase on the fermentation and microbiological composition of grass silage. II Microbiological changes in the silages
}

\author{
AINO RAURAMAA, JOUKO SETÄLÄ, TAUNO MOISIO and SEPPO SIVELÄ \\ Valio Co-operative Dairies' Association, \\ Research and Development Department \\ P.O. Box 176, SF-00181 Helsinki, Finland
}

TERTTU HEIKKILÄ and MARTTI LAMPILA

Agricultural Research Centre,

Department of Animal Husbandry

31600 Jokioinen, Finland

\begin{abstract}
Four experimental silages were made into bunker silos by adding lactic acid bacteria and cellulase enzyme. The control silages were made without any additives and with AIV II solution ( $80 \%$ formic acid, $2 \%$ orthophosphoric acid). The microbial compositions of the experimental silages were studied in five microbial groups: (1) total count of bacteria, (2) lactic acid bacteria, (3) clostridia, (4) coliform bacteria and (5) fungi (yeasts and moulds).

At the beginning of the fermentations enteric bacteria and lactic acid bacteria were increasing. Inoculation of the silage decreased the growth of enterobacteria compared with silages made with cellulase or without additives. This effect was further increased by using AIV II solution. Heterolactic fermentations started in the silages made with cellulase, inoculants and no additives, when initial reducing sugars, primarily glucose and fructose, were fermented. In good ensiling conditions only a few butyric acid forming clostridia and small amounts of moulds and yests were found. Yeasts existed mostly in silages made with cellulase and with inoculation.
\end{abstract}

Index words: Silage preservation, inoculants and enzyme, microbiological changes

\section{Introduction}

In the summer of 1985 four experimental silages were made from the first cut into bunker silos by adding lactic acid bacteria and cellulase enzyme. The control silages were made without any additives and with AIV II solution ( $80 \%$ formic acid, $2 \%$ orthophosphoric acid, $5.2 \mathrm{l} /$ ton grass). As reported by Rauramaa et al. (1987) formic 
acid restricted respiration and fermentation in AIV II silage. The lower contents of lactic, acetic and propionic acids, as well as ammonia- $\mathrm{N} \%$ from total- $\mathrm{N}$, temperature, and buffering capacity and the higher sugar content and better digestibility in vitro stand up for this conclusion. The changes in the micro-organisms of silage were studied during ensiling. The microbial compositions of the experimental silages were studied in five microbial groups: (1) total count of bacteria, (2) lactic acid bacteria, (3) clostridia, (4) coliform bacteria and (5) fungi (yeasts and moulds).

\section{Microbiological methods}

\section{Samples}

Samples for microbiological analyses were taken by hand using plastic gloves together with the samples for chemical analyses (see RauramaA et al. 1987). They were transported to the laboratory covered with ice and analyzed 2.5 hours after sampling. The size of a sample bag was about $1 \mathrm{~kg}$.

\section{Procedure}

$25 \mathrm{~g}$ of silage was weighted aseptically into a sterile plastic bag, $225 \mathrm{ml}$ sterile dilute solution (Ringer's solution quarter strength) was added. The silage was homogenized by a stomacher for one minute. Further decimal dilutions were made from this homogenate and each decimal dilution was used for the incubation of media. The bacterial groups determined and the media are described below:

Plate count, incubated aerobically at $30 \pm$ $1^{\circ} \mathrm{C}, 72 \pm 2$ hours (as described in FIL-IDF 100: 1980 and 109: 1982).

Anaerobic plate count, as plate count, incubated in anaerobic jars (BBL) with Anaerocult (E. Merck, 13 289)

Coliforms, incubated in VRB agar medium aerobically at $30 \pm 1^{\circ} \mathrm{C}$ for $24 \pm 2$ hours, as described in FIL-IDF 73: 1974

Enterobacteriaceae, as above with $1 \%$ glucose added.

Lactobacteriaceae, incubated anaerobically in MRS-agar medium at $30 \pm 1^{\circ} \mathrm{C}$ for $72 \pm$ 2 hours

Gibson's tests inoculation with $1 \mathrm{ml}$ of $1-2$ day culture incubated anaerobically in Gibson's medium at $30 \pm 1{ }^{\circ} \mathrm{C}$ (GiBson and ABDEl-Malek 1945). Results are expressed as a number of heterofermentative colonies from 10 colonies tested on each plate.

Yeasts and moulds, incubated aerobically in yeast extract-dextrose-chloramphenicol-agar medium at $25 \pm 1^{\circ} \mathrm{C}$ for 4 days, as described in FIL-IDF 94: 1980 (provisional)

Butyric acid clostridial spores, incubated anaerobically in BB-lactate broth medium. Results are expressed as MPN-values (BERGERE et al. 1969).

\section{Results and discussion}

As reported by RauramaA et al. (1987) the sugar content of raw material sward was high, over $15 \%$ in dry matter. From the sugars two thirds were glucose, fructose, and sucrose. Also the silage making technique was good. According to the contents of carbon dioxide in the silages (RAURAMAA et al. 1987) oxygen was consumed very rapidly in the fodder mass and the careful compacting and covering prevented the access of oxygen of the air into the silages. Therefore in all the experimental silages there was a good opportunity for homofermentative lactic acid fermentation.

\section{Total count of bacteria}

In the raw material the total leaf surface population or epiphytic microflora varied on the plate count from $10^{6}$ to $10^{8} \mathrm{cfu} \mathrm{g}^{-1}$ fresh weight. The average contents of aerobic bacteria was $4.5 \times 10^{7} \mathrm{cfu} \mathrm{g}^{-1}$ fresh weight, and that of anaerobic bacteria $1.2 \times 10^{5} \mathrm{cfu} \mathrm{g}^{-1}$ fresh weight. These figures were within the ranges expressed by Kroulik et al. (1955 a, b), 

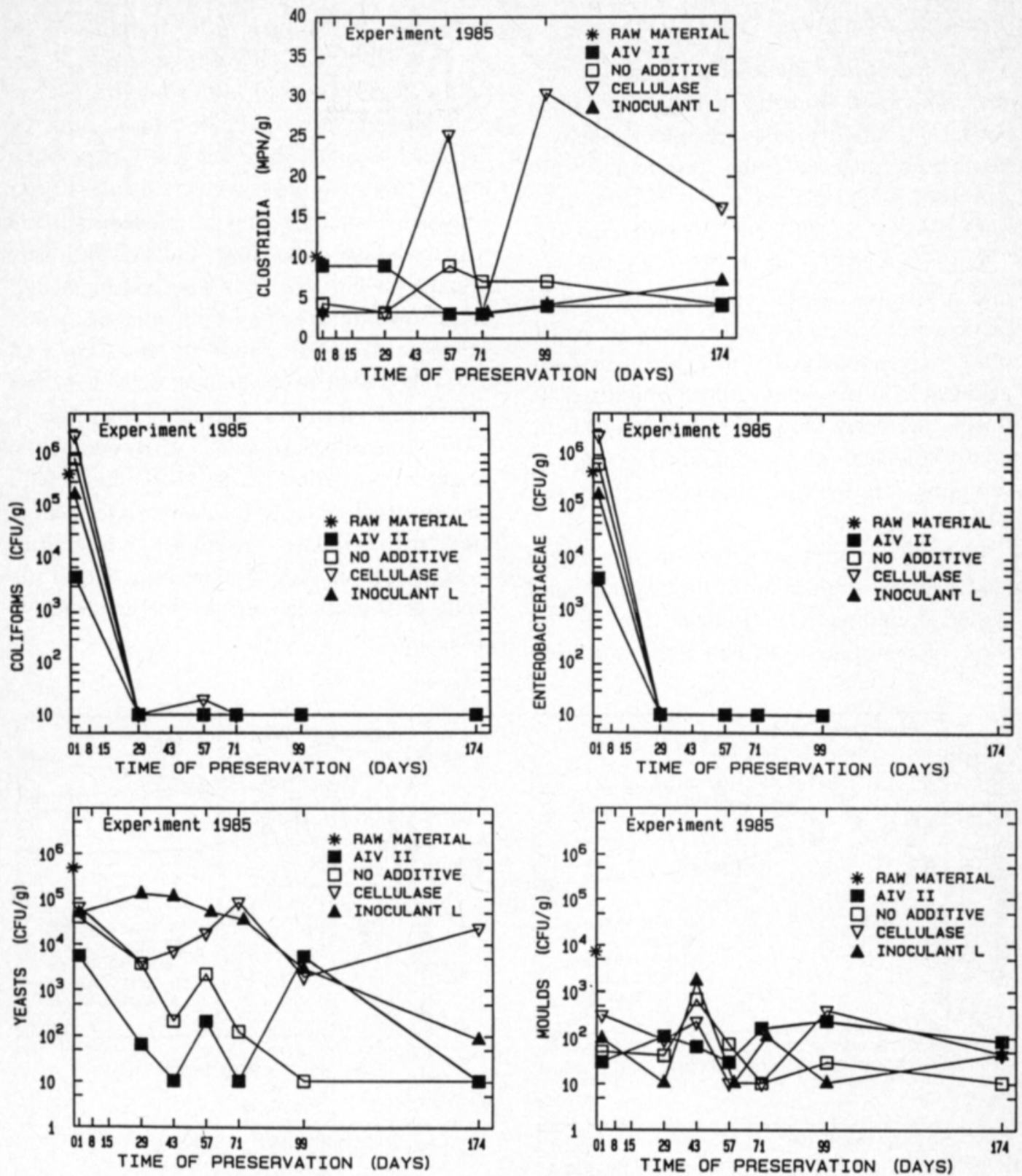

Fig. I. The changes of the microbiological contents in the experimental silages made with AIV II solution, no additives, cellulase or inoculants.

Nilsson and Nilsson (1956), GiBson et al. (1958 and 1961), LAngSton et al. (1962) and WOOLFORD (1984).

The contents of aerobic bacteria on plate count varied during the preservation period. Most of them were apparently facultative anaerobes. According to chemical analyses there was not any fermentation in AIV II silage (RAURAmAa et al. 1987) and the contents of microbes decreased (Fig. 1 and 2) during the first preservation day. In the contents of aerobic and anaerobic bacteria of every experimental silage the decrease occurred after four weeks from the filling of the silos. 


\section{Lactic acid bacteria}

The contents of lactic acid bacteria in raw material varied from $10^{2}$ to $10^{5} \mathrm{cfu} \mathrm{g}^{-1}$ fresh weight. Generally grasses are a poor source of lactic acid bacteria, often less than $10^{2} \mathrm{cfu}$ $\mathrm{g}^{-1}$ fresh weight (STIRLING and Whittenbury 1963, Woolford 1984, Silley and Damoglou 1985). Lindgren et al. (1985 a) and Ojala and Poutiainen (1986) reported contents of lactic acid bacteria in grasses from $10^{2}$ to $10^{6}$ $\mathrm{cfu} \mathrm{g}^{-1}$ fresh weight. In our experiment lactic acid bacteria might have been able to grow during the delay between the starting of the microbiological analyses and the time of sampling, though the samples were covered with crushed ice.

During the first preservation day lactic acid bacteria multiplied in the experimental silages excluding AIV II silage (Fig. 2) and the contents of lactic acid bacteria were simi- lar in the silages made with inoculants, cellulase or without additives. In all these silages was a clear decrease in the content of lactic acid bacteria just as in the total count of aerobic and anaerobic bacteria. It is possible that at that juncture lactic acid bacteria flora changed its metabolisms in the silages made with cellulase, inoculants and no additives, because the hexose-sugars were consumed and at the same time the redox potential decreased significantly as described by RAURAMAA et al. (1987), and according to Gibson's tests heterolactic bacteria started to increase in those three silages (Fig. 2). At the end of the preservation period nearly all the lactic acid bacteria were heterofermentative in the silages made with cellulase, inoculants and no additives whereas in AIV II silage only half of the lactic acid bacteria were heterofermentative (Fig. 2).
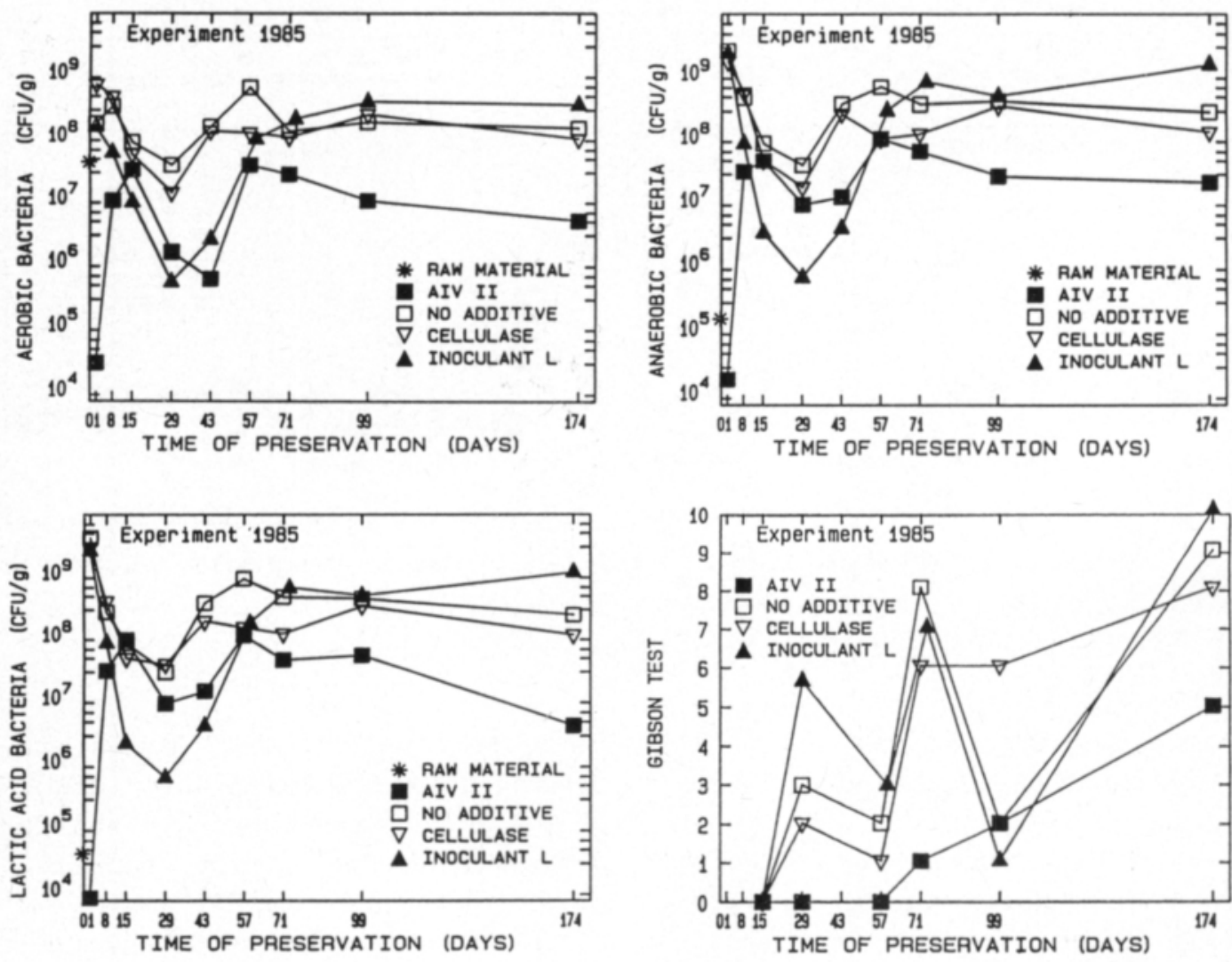

Fig. 2. The changes of the microbiological contents in the experimental silages made with AIV II solution, no additives, cellulase or inoculants. 
The amount of the added lactic acid bacteria was $7 \times 10^{5} \mathrm{cfu}^{-1}$ grass in the inoculated silage. This addition was not seen in the contents of lactic acid bacteria, of the inoculated silage compared with those of lactic acid bacteria in the cellulase treated and untreated silages (Fig. 2). The contents of lactic acid bacteria and also the production of lactic acid were lowest in AIV II silage (RAURAmAA et al. 1987). It is clear that the addition of formic acid not only restricted the growth of lactic acid bacteria, but also selected the strains of lactic acid bacteria (Fig. 2, Gibson test). This is in agreement with McDonald, 1981.

\section{Butyric acid clostridia}

Relatively low amounts of clostridia appeared in grass, 3-25 MPN g ${ }^{-1}$ fresh weight (Fig. 1). Clostridia are not normally included in grass microflora; they are contaminants from the soil entering the grass during harvesting. Owing to the good harvesting technique only a few clostridia spores and no butyric acid were found in the experimental silages (RAuramaA et al. 1987).

\section{Coliform bacteria}

Coliform bacteria belong to the family of Enterobacteriaceae. The contents of these bacteria were $1.1-4 \times 10^{5} \mathrm{cfu}^{-1}$ fresh weight in the raw material of experimental silages. During the first preservation day, reducing factors for enterobacteria were formic acid and low $\mathrm{pH}$ values. The acid treatment produces plasmolysis in fresh fodder. It is therefore easier to compact acid treated grass and to get it airtight during the filling of the silo. Coliform bacteria, yeasts and moulds, which cause aerobic deterioration (LINDGREN et al. 1985 b), can consume only oxygen dissolved in the effluent of silage. In our experiment the role of coliform bacteria was found to be connected with the fermentation of the first preservation days (Fig. 1). According to
Kroulik et al. (1955 a, b) coliform bacteria disappear within a few days from silages, of which $\mathrm{pH}$ values decrease rapidly.

The inoculation of lactic acid bacteria had a decreasing effect on the growth of enterobacteria in this experiment (Fig. 1). Further, the end products of fermentations were different qualitatively and quantitatively in the inoculated silage compared with the silage made with no additives (RAuramaA et al. 1987). During four weeks the enterobacteria incubated with or without glucose decreased below $10 \mathrm{cfu}^{-1}$ fresh weight in all the experimental silages. In good silages coliform bacteria were not found to a greater extent than in our earlier unreported experiments.

\section{Fungi}

Yeasts are usually connected to initial aerobic spoilage of silages (BECK and Gross 1964, WoOlFord et al. 1979, MoOn et al. 1980, Dellagio 1985). Such results have also been reported where many different microorganisms have been found to be responsible for aerobic deterioration (OHSHIMA and McDonald 1978, Crawshaw et al. 1980, WoOlFord 1984, LindGREN et al. 1985 b). In our experiment the contents of yeasts in the raw material were an average of $3.9 \times 10^{5} \mathrm{cfu}$ $\mathrm{g}^{-1}$ fresh weight and the contents of moulds were respectively $2.1 \times 10^{4} \mathrm{cfu}^{-1}$. During the preservation period the contents of yeasts and moulds reduced in all silages (Fig. 1).

The highest levels of yeasts were in the inoculated and cellulase treated silages, the averages being $2.6 \times 10^{4}$ and $5.0 \times 10^{4} \mathrm{cfu}^{-1}$ fresh weight. These silages had also the highest concentration of ethanol as reported by RAURAMAA et al. (1987). In previous studies most of the yeasts were found in the prewilted, formic acid-treated silage by HENDERSON et al. (1972), and slightly higher yeast and mould counts in the laboratory experiment for the formic acid-treated materials were reported by LINDGREN et al. (1985 a). In our experiment the contents of moulds decreased their level being $10^{2} \mathrm{cfu} \mathrm{g}^{-1}$ fresh weight. All the above 
mentioned contents of yeasts and moulds in the experimental silages were low and the effect of these micro-organisms on fermentation remained slight.

In conclusion all the experimental silages were organoleptically good, but according to the chemical analyses there occurred some differences which were in accord with the microbiological analyses. At the beginning of the fermentations enteric bacteria were increasing. Inoculation of the silage decreased the growth of enterobacteria compared with silages made with cellulase or without additives. This effect was further increased by using AIV II solution. Heterolactic fermenta- tions started in the silages made with cellulase, inoculants and no additives, when initial reducing sugars, primarily glucose and fructose, were fermented. In the present good ensiling conditions only a few butyric acid forming clostridia and small amounts of moulds and yeasts were found. Yeasts existed mostly in silages made with cellulase and with inoculation.

Acknowledgements. The authors would like to thank the staff of the Agricultural Research Centre and the chemical and microbiological groups in the Research and Development Department of Valio for their technical assistance.

\section{References}

BECK, TH. \& Gross, F. 1964. Ursachen der unterschiedlichen Haltbarkeit von Gärfutter. Das Wirtschafsteigene Futter. 10: 298-312.

Bergere, J-L., Rousseaux, P., Ducruct, P., Mocquot, G., Hermier, J., Gouet, P. \& Zelter, S.Z., 1969. Experimantation sur la Fabrikation d'Emmental et de Comete avec du lait de vaches norries à l'ensilage A.I.V. 1. - Aspects technologiques Extrait du »Bulletin Technique d'Information». 239: 1-37.

Crawshaw, R., Thorne, D.M. \& Llewelyn, R.H. 1980. The effects of formic and propionic acids in the aerobic deterioration of grass silage in laboratory units. J. Sci. Food Agric. 31: 685-694.

Dellaglio, F. 1985. Lactic acid bacteria in silage fermentation. Microbiologie - Aliments - Nutrition: 3: 91-104.

Gibson, T. \& ABd-El-MALEK, Y. 1945. The formation of carbon dioxide by lactic acid bacteria and Bacillus licheniformis and a culture method for detecting the process. J. of Dairy Res. 14: 35-44.

Gibson, T., Stirling, A.C., Keddie, R.C. \& Rosen. BERGER, R.F. 1958. Bacteriological changes in silages made at controlled temperatures. J. Gen. Microbiol. 19: 112-129.

Gibson, T., Stirling, A.C., Keddie, R.C. \& Rosen. BERGER, R.F. 1961. Bacteriological changes in silage as affected by laceration of the fresh grass. J. Appl. Bact. 24 (1): $60-70$.

Henderson, A.R., McDonald, P. \& Woolford, M.K. 1972. Chemical changes and losses during the ensilage of wilted grass treated with formic acid. J. Sci. Fd. Agric. 23: 1079-1087.

Kroulik, J.T., Burcki.ey, L.A. \& Wiseman, H.G. 1955 a.

The microbial populations of the green plant and of the cut forage prior to ensiling. J. Dairy Sci. 38: 256-262.

Kroulik, J.T., Burckley, L.A., Gordon, C.H., Wise. Man, H.G. \& MEl.ın, C.G. 1955 b. Microbial activities in alfalfa and orchard grass ensiled under certain conditions in experimental silos. J. Dairy Sci. 38: 263-272.

Langston, C.W., Bouma, C. \& Conner, R.M. 1962. Chemical and bacteriological changes in grass silage during the early stage of fermentation. II. Bacteriological changes. J. Dairy Sci. 45: 618-624.

Lindgren, S., Pettersson, K., Jonsson, A., Lingwall, P. \& KASPERSSON, A. 1985 a. Silage inoculation. Swedish J. agric. Res. 15: 9-18.

Lindgren, S., Pettersson, K., Kaspersson, A., Jonsson, A. \& Lingvalt, P. 1985 b. Microbial dynamics during aerobic deterioration of silages. J. Sci. Food Agric. 36: 765-774.

McDonald, P. 1981. The Biochemistry of silage. Chichester, John Wiley \& Sons. 226 p.

Moon, N.J., Ely, L.O. \& Sudweeks, E.M. 1980. Aerobic deterioration of wheat, lucerne and maize silages prepared with Lactobacillus acidophilus and a Candida spp. J. Appl. Bact. 49: 75-87.

Nusson, G. \& Nulsson, P.E. 1956. The microflora on the surface of some fodder plants at different stages of maturity. Archiv für Microbiologie. 24: 412-422.

Ohshima, M. \& McDonald, P. 1978. A review of the changes in nitrogenous compounds of herbage during ensilage. J. Sci. Fd. Agric. 29: 497-505.

Ojala, R. \& Poutiainen, E. 1986. The use of lactoacid bacteria preparate in grass silage making. Helsingin yliopisto. Kotieläintieteen laitoksen tiedote nro 8: 1-38. 
Rauramaa, A., Setal.a, J., Moisio, T., Heikkilä, T. \& LAMPILA, M. 1987. The effect of inoculants and cellulase on the fermentation and microbiological composition of grass silage. Part 1. Biochemical changes in the silages. J. Sciest. Agric. Soc. Finl. 59: 361-370.

Siley, P. \& Damoglou, A.P. 1985. The effect of three commercial silage additives on numbers of lactobacilli entering the silo at the onset of fermentation. FEMS Microbiology Letters 30: 107-110.

Stirling, A.C. \& Whittenbury, R. 1963. Sources of the lactic acid bacteria occurring in silage. J. Appl. Bact.

\section{SELOSTUS}

\section{Maitohappobakteeri- ja sellulaasientsyymi- lisäyksen vaikutus nurmisäilörehun käymiseen ja mikrobiologiseen koostumukseen. II Mikrobiologiset muutokset säilörehussa}

\author{
Aino Rauramaa, Jouko Setälä, Tauno Moisio \\ ja Seppo Sivelä
}

Valio Meijerien Keskusosuusliike

Tutkimus- ja tuotekehittelyosasto

PL 176, 00181 Helsinki

\section{Terttu Heikkilä ja Martti Lampila}

\section{Maatalouden Tutkimuskeskus \\ Kotieläinhoidon Tutkimuslaitos \\ 31600 Jokioinen}

Kesällä 1985 valmistettiin koiranheinä-timoteinurmesta (1 : 2) neljä koesäilörehua Maatalouden Tutkimuskeskuksen Lintupajun koetilalla. Säilöntäaineet olivat: maitohappobakteerit, sellulaasientsyymi ja AIV II -liuos. Yksi rehu valmistettiin ilman säilöntäainetta.

Säilönnän aikana kảymisiả seurattiin kairaamalla otetuista näytteistă sekä kemiallisten analyysien että mikrobiologisten määritysten avulla. Rehunäytteistä määritettiin viisi mikrobiryhmaaä: (1) bakteerien kokonaismäärä, (2) maitohappobakteerit, (3) voihappobakteerien itiöt,

(4) koliryhmän bakteerit ja (5) homeet ja hiivat.
26 (81): $86-90$.

WoOlford, M.K. 1984. The silage fermentation. New York. 350 p.

Woolford, M.K., Honig, H. \& Fenton, S.J. 1979. Untersuchungen über den aerobem Abbau in Silage mit einer Labormetode. Teil 3: Microbiologische, physikalische und chemische Veränderungen während des aeroben Abbau in frischer und angewelkter Grasssilage. Das Wirtschafteigene Futter 25 (2/3): 158-177.

Ms received June 17, 1987
Mikrobitulokset osoittavat, ettă säilönnän alkuvaiheessa lisääntyvät lähinnä koliryhmän bakteerit ja maitohappobakteerit. Maitohappobakteerien lisäys rehumassaan vaikutti vähentävästi koliryhmän bakteerien kasvuun verrattaessa tătä rehua ilman säilöntäainetta ja sellulaasilisäyksellä valmistettuun rehuun. AIV II -liuoslisäys hillitsi kaikkia kảymisiă ja suosi homofermentatiivisia maitohappobakteereita. Hyvistä säilöntäolosuhteista johtuen rehuissa oli vain vähän voihappobakteerien itiöită, hiivoja ja homeita. Eniten hiivoja esiintyi sellulaasilla ja maitohappobakteerilisäyksellä valmistetuissa rehuissa. 